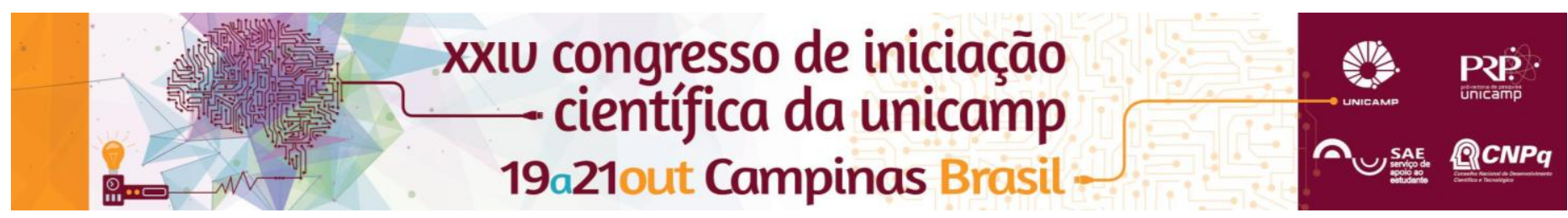

\title{
Do genoma ao produto natural: estudo dos agrupamentos biossintéticos e os metabólitos da linhagem Streptomyces wadayamensis A23.
}

\section{Ana B. Gonçalves*, Luciana G. de Oliveira}

\section{Resumo}

Micro-organismos produzem metabólitos importantes para a sua autogenia. Muitas vezes esses compostos possuem atividades farmacológicas importantes e de grande interesse para a humanidade, tais como antibióticos, herbicidas, vermífugos entre outros. A avaliação do perfil metabólico sob diversas condições nutricionais e a utilização de ferramentas tais como ensaio guiado, genome mining com aproximação genomisotópica e experimentos de deleção e análise do genoma para a elucidação das estruturas dessas moléculas foram os objetivos deste projeto.

\section{Palavras-chave:}

Genoma, Streptomyces, metabólitos.

\section{Introdução}

Streptomyces são actinobactérias gram-positivas com alto conteúdo $G+C$, conhecidas pela produção de antibióticos usados em infecções bacterianas em humanos. ${ }^{1}$ A análise recente do genoma de diversas linhagens de Streptomyces revelou uma grande abundância de agrupamentos de genes que codificam enzimas do metabolismo secundário. ${ }^{2}$

Experimentos de deleção genética, que são realizados juntamente com os experimentos de incorporação de reagentes marcados, também permitem elucidar os metabólitos responsáveis pelas atividades observadas além de associar os metabólitos aos agrupamentos de genes que os biossintetizam.

O estudo proposto neste projeto envolve elucidar a estrutura de metabólitos do grupo dos PKs e NRPs da linhagem S. wadayamensis A23 fazendo-se uso das informações geradas a partir do sequenciamento completo do genoma das linhagens de interesse por um processo de genome mining.

\section{Resultados e Discussão}

A avaliação do perfil metabólico em diferentes condições nutricionais utilizando a espectrometria de massas confirmou a presença dos metabólitos candicidina, antimicinas e desferroxamina B. Uma molécula cuja massa/carga é 912 e a estrutura definitiva permanece desconhecida foi atribuída como um peptídeo nãoribossomal linear. ${ }^{3}$

Para os experimentos de deleção gênica, selecionaramse seis agrupamentos biossintéticos que se relacionam a produção de metabólitos conhecidos e que podem estar associados à atividade antibiótica do micro-organismo.

Usando um protocolo bem estabelecido, conhecido por Gibson Assembly, realizou-se a montagem do plasmídeo de deleção usando o plasmídeo pYH7 e a E. coli DH10B para a clonagem. Os agrupamentos, bem como seus metabólitos seguem descritos na Tabela 1.

Tabela 1: Relação das amostras (de 1 a 6 ) com os clusters e metabólito previsto.

\begin{tabular}{|c|c|c|}
\hline Amostra & Cluster & Tipo de cluster \\
\hline 1 & 15 & $\begin{array}{c}\text { Lantipeptideo T1 NRPS-PKS } \\
\text { (sintetase das antimicinas) }\end{array}$ \\
\hline 2 & $15 \mathrm{~A}$ & $\begin{array}{c}\text { Lantipeptideo T1 NRPS-PKS } \\
\text { (sintetase das antimicinas) }\end{array}$ \\
\hline
\end{tabular}

\begin{tabular}{|c|c|c|}
\hline 3 & 17 & $\begin{array}{c}\text { NRPS (sintetase da } \\
\text { manopeptimicina) }\end{array}$ \\
\hline 4 & 2 & NRPS \\
\hline 5 & 5 & T1PKS \\
\hline 6 & 7 & NRPS \\
\hline
\end{tabular}

Dois plasmídeos de deleção foram obtidos com sucesso (quando submetidos à PCR de colônias e analise com enzima de restrição Ndel indicaram a presença do DNA recombinante). Essas construções correspondem às amostras 1 e 3 e se mostram interessantes visto que a manopeptimicina é prevista no genoma porém ainda não foi encontrada em S.wadayamensis. Experimentos para a promoção da linhagem de S. wadayamensis mutante já estão em andamento, e nas próximas etapas novas avaliações do perfil metabólico e da atividade antibiótica devem ser realizadas.

\section{Conclusões}

A avaliação do perfil metabólico por espectrometria de massas indicou a presença de moléculas já conhecidas, tais como as antimicinas, desferroxaminas e candicidina e também indicou a presença de moléculas cujas estruturas ainda permanecem desconhecidas, como os íons 912 e 639. Nos experimentos de deleção dois plasmídeos foram obtidos com sucesso. Os genes e os respectivos agrupamentos de genes biossintéticos envolvidos nesses experimentos codificam para a produção das antimicinas (cluster tipo misto) e manopeptimicina (cluster tipo NRPS). A primeira parte desse projeto de pesquisa foi recentemente publicada no artigo Genome Mining of endophytic Streptomyces wadayamensis reveals high antibiotic production capability (referência 3 ).

\section{IQ- Unicamp, SAE}

\section{Agradecimentos}

\footnotetext{
${ }^{[1]}$ Scheer, N.; Nguyen, L. Curr. Opin. Microbiol., 2009, 12, 699.

${ }^{[2]}$ De Oliveira, L. G.; Pupo, M. T.; Vieira, P. C. Quim. Nova, 2013, 36, 1577 1586

[3] Angolini, C. F. F.; Gonçalves, A. B.; P. L. R. Cruz, P. L. R.; Samborskyy, M.; Sigrist, R.; Paulo; B. S.; Vivian, A. F.; Schmidt, E. M.; Eberlin, M. N.; Araújo, W. L.; de Oliveira, L. G. J. Braz. Chem. Soc. 2016
} 